\title{
THOUGHTS ON A THINKER-BASED APPROACH TO FREEDOM OF SPEECH
}

\author{
(Accepted 18 January 2019)
}

\begin{abstract}
While agreeing with Seana Shiffrin that any free speech theory must depend on assumptions about our need for free thinking, I am sceptical about her claim that her thinker-based approach provides the best explanation for freedom of speech. Her argument has some similarities with Mill's argument from truth and with self-development theories, though it improves on the latter. But the thinkerbased approach does not show why political discourse, broadly construed, is protected more strongly in all jurisdictions than gossip and sexually explicit speech. Nor does it explain why the 'mass' speech of corporations and the mailings of political parties and charities are fully protected by provisions such as the First Amendment. My article concludes with some reflections on the relationship of abstract political theory such as Shiffrin's to constitutional law; abstract theory must inevitably make some compromises if it is fully to explain constitutional jurisprudence.
\end{abstract}

Seana Shiffrin's thinker-based approach to freedom of speech is a rich and ambitious intellectual enterprise. It argues that freedom of speech is necessary for the development of individuals as thinkers, for freedom of thought and for the moral quality of human relations. The approach, she claims, provides a stronger foundation for free speech protection than competing theoretical approaches, ${ }^{1}$ for example, the arguments from the importance of discovering truth and from the role of free speech in the working of a participatory democracy. Indeed the other theories 'presuppose...that there is a developed thinker behind the scenes - one who speaks, listens, or contributes to government, and whose self-expression, reactions to information and others' expression....are, at least potentially, of sufficient moment that they merit fundamental protection.' ${ }^{2}$ The

\footnotetext{
${ }^{1}$ Speech Matters, 80.

${ }^{2}$ Ibid., 84-85.
} 
autonomy of individual minds and their needs underlies other free speech theories, which on their own provide only a partial explanation of the freedom. Shiffrin does not claim that the thinker-based theory explains everything about freedom of speech, but it provides a structure which can accommodate other values and which connects the ethical foundations of freedom of communication to the ethical constraints on its exercise. ${ }^{3}$

I have no difficulty with much of this argument. I agree that the other approaches to free speech theory fail to provide a satisfying, let alone a complete, explanation of the free speech jurisprudence of the U.S. Supreme Court (or the European Court of Human Rights), let alone to justify it or determine how it ought to develop. Further, it must be right that any free speech theory assumes, or more accurately ascribes, a degree of rationality to human beings - their capacity often, perhaps even generally, to distinguish true from false claims, and to assimilate information and the ideas of other people. Without any capacity for rational thought and in the absence of autonomy to act on such thought, none of the arguments for freedom of speech would make much sense; any version of the free speech argument from democracy, for example, surely assumes that individuals can process the rival claims of political parties and candidates. Moreover, it is on the occasions when we have strong grounds to be sceptical of human rationality and autonomy arguments that we have some justification for limiting freedom of speech, for example, the freedom to circulate misleading commercials and to advertise products such as tobacco or sugary drinks or (more controversially) media publicity which risks prejudicing a fair trial.

I agree then with Seana Shiffrin insofar as she argues that free speech theories must depend on assumptions about our need for free thinking in order to develop our capacity for ratiocination, to discern the truth, to exercise imagination, and so on. ${ }^{4}$ But her thinker-based approach makes the stronger claim that it provides the best explanation for the protection of freedom of speech, and certainly a more persuasive explanation than other theories. For reasons developed in section III of this paper, I find it difficult to accept this stronger claim.

\footnotetext{
${ }^{3}$ Ibid., 85-86.

${ }^{4}$ Ibid., 86-88.
} 
Before that, I compare Shiffrin's thinker-based approach with two other free speech theories - Mill's argument from truth and selfdevelopment arguments - a comparison which might help to appreciate its strengths and weaknesses: see sections I and II. This paper concludes in section IV with a few reflections on the relationship of abstract political philosophy on freedom of speech to constitutional and legal reasoning about the freedom. ${ }^{5}$

\section{SHIFFRIN AND MILL}

Shiffrin's theory seems to me to have some affinity with the ideas in Mill's famous essay, 'Of the Liberty of Thought and Discussion. ${ }^{6}$ For Mill the liberty of expressing and publishing opinion was 'practically inseparable' from freedom of thought. ${ }^{7}$ It was impossible to separate that liberty from the cognate liberty of speaking and writing. ${ }^{8}$ It was important to enable even average persons to attain the mental stature of which they are capable, and to develop the intellect and judgement of mankind. ${ }^{9}$ People had a 'fatal tendency' to give up thinking about matters once they were regarded as beyond doubt, so they were no longer able to explain and defend them in a lively manner. ${ }^{10}$ I feel sure Shiffrin would applaud all of that.

But there are at least two significant differences. In the first place, there is a distinction between Mill's largely consequentialist defence of freedom of discussion - the discovery of truth benefits mankind and advances social progress - and Shiffrin's deontological theory linked to the autonomy of individuals. Speech, she argues, is the only precise route by which each individual is known to another. Further, '[i]t is important in itself that one be known as the distinct individual one is' (my emphasis). ${ }^{11}$ Secondly, there is a radical difference with regard to the scope or categories of speech covered by the two theories. Mill was primarily concerned with the dissemination of political, religious and moral opinion. He was unconcerned with attacks on the conduct of ordinary individuals, and with personal or

\footnotetext{
${ }^{5}$ These reflections could be applied to other rights, for example, privacy or equality rights.

${ }^{6}$ Essay II in On Liberty, ed J Gray (Oxford UP, 1991).

${ }^{7}$ Ibid., 16-17.

${ }^{8}$ Ibid., 19.

${ }^{9}$ Ibid., 37-39, and 41.

${ }^{10}$ Ibid., 49-50.

${ }^{11}$ Ibid., 89.
} 
celebrity gossip, or at least he did not address these free speech topics. And his theory is hard to apply to non-propositional speech that is expression which simply expresses a personal feeling or outrage - and which cannot be identified as true or false. Shiffrin's approach in contrast would cover a very wide range of speech, not just political and religious discourse, but diaries, letters and conversations. ${ }^{12}$ I return to this important feature of her argument later in section III; I want merely to point out here that Shiffrin differs from Mill in being unconcerned with the type of speech at issue and in particular whether it is capable of contributing to the discovery of truth for the benefit of mankind.

\section{SHIFFRIN AND SELF-DEVELOPMENT THEORIES}

A number of US writers on freedom of speech have argued that the First Amendment is best explained and justified in terms of the selfdevelopment, self-expression or self-realization of those engaged in speech. ${ }^{13}$ In the version advocated by Ed Baker - what he terms the 'liberty model' - the argument rests on respect for 'people's integrity as rational, equal autonomous moral beings. ${ }^{14}$ These self-development theories usually emphasise the speaker's autonomy to articulate her thoughts to others or just to herself in reverie, diaries and other unpublished form. In contrast, other autonomy theories, notably that of Thomas Scanlon, ${ }^{15}$ are based on the autonomy of listeners in access to all arguments enabling them to formulate their beliefs and to choose whether to act on them. Self-development and autonomy theories, therefore, vary considerably one from another.

But these arguments are all open, admittedly in varying degrees, to the criticism that they do not distinguish the arguments for a free speech principle, or in legal terms for the strong constitutional protection provided, say, by the First Amendment, from general libertarian claims. Why are the values of self-development or individual autonomy better served by freedom of speech and communication than by other goods, such as sexual activity, full employment and adequate housing, which are not generally guar-

\footnotetext{
${ }^{12}$ Ibid., 93-4.

${ }^{13}$ For example, CE Baker, 'Scope of the First Amendment Freedom of Speech' (1978) 25 UCLA Law Rev 964; M Redish, 'The Value of Free Speech' (1982) 130 University of Pennsylvania Law Rev 591.

${ }^{14}$ Baker, 'Scope of the First Amendment Freedom of Speech' (n 13) 992.

15 'A Theory of Freedom of Expression' (1972) 1 Philosophy and Public Affairs 204.
} 
anteed in liberal constitutions? For many people, these goods are at least as important as an unimpeded right to impart or receive information and ideas. Even if a premium is put on intellectual or mental self-development, it is not obvious why speech should be more strongly protected than education, travel, and the variety of life experiences which are also necessary to achieve this type of development. In short, self-development and other similar theories do not explain why, as Fred Schauer has put it, speech is special. ${ }^{16}$

First, should Seana Shiffrin's thinker-based approach be regarded as akin to the self-development or autonomy theories of free speech, and second, is it open to the same criticism that it does not explain why speech is special? The first question may not be very important. Like Baker's liberty model, Shiffrin's theory is concerned with individual autonomy and self-fulfilment, and with everyone's development as a distinctive personality. On both theories, the solitary uses of speech are regarded as equally worthy of protection as the communication of ideas to others. Human beings develop if they are free to formulate their thoughts and ideas through the writing of poetry and personal diaries or the chanting of political slogans, whether or not they are read or heard. ${ }^{17}$ But unlike Baker, Shiffrin does not lay stress on the speaker's interest rather than that of the listener; her theory is more concerned with that of the human agent as a thinker who both speaks and listens.

But the second question is significant, and Shiffrin herself provides an answer to it. ${ }^{18}$ Speech is more precise and informative about the contents of a thinker's mind than other forms of expression - intimate sexual activity to communicate affection or punching someone to communicate anger - so there is a good reason for treating speech as special. ${ }^{19}$ A variety of experience - different types of work, travel, living in other cultures - may be essential for intellectual development, but speech is necessary for the interpretation of, and reflection on, these types of experience. The freedom to communicate ideas

\footnotetext{
16 'Must Speech be Special?' (1983) 78 Northwestern University Law Rev 1284, 1289-93. Also see F Schauer, Free Speech: A Philosophical Enquiry (Cambridge Univ Press, 1982) 50-58.

${ }^{17}$ Baker (n 13) 994-96; Shiffrin, 86 (the theory 'encompasses both freedom of thought and freedom of communication, with oneself and with others') and 89-90.

${ }^{18}$ Shiffrin, 106-115.

${ }^{19}$ In $7215 / 75, X v$ UK 19 D \& R 66 the European Human Rights Commission rejected an application that homosexual conduct was covered by ECHR, art 10 guarantee of freedom of expression as expressing the participants' feelings for each other.
} 
and information by speech is more closely related to our development as thinkers, as moral agents and autonomous human beings than are other freedoms, for example, to choose a form of sexual intimacy or when to end our life, which are more appropriately protected under privacy and dignity rights. I find this part of her argument extremely persuasive.

What it does not show is why intellectual self-fulfilment is more important to human development than the satisfaction of other, more material wants. But Shiffrin's theory starts from her argument (in chapter 1) that communication plays a special role in our moral understanding of each other, so the central importance of thought and reflection for human autonomy, or in other words of intellectual development, can perhaps be taken as axiomatic for her justification of freedom of speech. Though the thinker-based approach has some similarities with self-development theories, it is based on different foundations which take for granted the special role of thought, reflection, and the imagination.

\section{DOES THE THINKER-BASED APPROACH EXPLAIN FREEDOM OF SPEECH?}

Shiffrin's bold claim is that her thinker-based approach illuminates specific legal systems of free speech protection and provides a critique for their reform and development. The approach can be applied to any jurisdiction although her argument understandably is illustrated by US court decisions. ${ }^{20}$ It also justifies the (constitutional) protection of freedom of speech though the evolution of specific areas of free speech doctrine can be shaped by other values. ${ }^{21}$ I understand the claim to mean that her approach goes some way to explain free speech law and to indicate how it might best be developed. Shiffrin uses her arguments to support protection for a very wide, indeed perhaps unlimited, range of speech: not just political and religious discourse, but fiction, art, and private speech, for example, 'personal conversations and letters that, however trivial the subject, are crucial to developing, pursuing, and maintaining personal relationships. ${ }^{22}$ Her theory does not therefore relegate

\footnotetext{
${ }^{20}$ Shiffrin, 82 .

${ }^{21}$ Ibid., 85-86.

22 Ibid., 93-94.
} 
gossip and the disclosure of thoughts about personal relations to a lower position in the free speech pantheon, as do the democracy and truth theories. $^{23}$ For Shiffrin that is a merit of her thinker-based approach.

Her approach has then radically different implications from those suggested by Mill's argument from the importance of truth and by the 'public discourse' argument advanced by, among others Robert Post and James Weinstein. ${ }^{24}$ As already noted, Mill's truth argument applies to the dissemination of political and religious opinion but probably not to non-propositional or personal speech. Public discourse theory privileges speech which contributes to the consideration by society of any matter relevant to its government and what it believes. But family conversations, even about national politics, might not be covered as they probably do not constitute part of that public debate. ${ }^{25}$

On the thinker-based approach, it would be wrong to treat some categories of speech as less worthy of protection than others, in particular the political and religious discourse which is entitled to very strong protection under competing free speech theories. But in both the USA and in England, stronger protection is given to speech about politics and public affairs than it is, say, to (hard-core) pornography, personal gossip, or to commercial speech and advertising. ${ }^{26}$ Seana Shiffrin does agree that commercial and corporate speech falls outside her theory as it does not emanate from autonomous, individual thinkers. ${ }^{27}$ But sexually explicit speech and privacy-infringing personal gossip are as fully entitled to protection on her theory as political discussion. The theory does not, therefore, well explain or illuminate the state of free speech law in the USA or in England, or for that matter in other Western democracies.

\footnotetext{
${ }^{23}$ Ibid., 93.

${ }^{24}$ R Post, 'Participatory Democracy and Free Speech' (2011) 97 Virginia Law Rev 477; J Weinstein, 'Participatory Democracy as the Central Value of American Free Speech Doctrine' (2011) 97 Virginia Law Rev 491.

${ }^{25}$ See R Post, 'Participatory Democracy as a Theory of Free Speech: A Reply' (2011) 97 Virginia Law Rev 617, 623.

${ }^{26}$ This is an oversimplification of the US position, but some Supreme Court decisions do hold that commercial speech and pornography do not enjoy the same degree of protection as political speech; see Central Hudson Gas \& Electricity Corp. v Public Service Commission 447 US 557 (1980) for commercial speech, and Young $v$ American Mini Theatres 427 US 50 (1976) (sexually explicit material treated as low value speech). For an authoritative exposition of the position in England, see the judgements of Lady Hale in Campbell v MGN [2004] 457 [143]-[148] (political, intellectual and educational speech entitled to greater protection than gossip about a celebrity) and in Miss Behavin' Ltd v Belfast City Council [2007] 1 WLR 1420 [38] (pornography below celebrity gossip in hierarchy of speech).

${ }^{27}$ Shiffrin, $98-102$.
} 
Let me develop this point with an example from defamation law. In the USA, it is virtually impossible for a public official or public figure to win libel damages, because of the exceptionally strong protection given to the publication of defamatory allegations about such persons under the constitutional principle established by the Supreme Court in New York Times $v$ Sullivan and its subsequent rulings extending that decision to public figures. ${ }^{28}$ Under English defamation law, there is now a broad qualified privilege for the publication of allegations which are, or are part of, a statement on a matter of public interest, where the defendant - generally the media - reasonably believed that publication was in the public interest. ${ }^{29}$ These principles are easily explained and justified in terms of the higher value or importance attached by US and English law to speech on matters of public interest (not confined to politics) than to speech on a purely private matter or, in the United State, about a private individual; the former category of speech, but not the latter, trumps the conflicting right to reputation. But speech on public and private matters is entitled to the same level of protection on the thinker-based approach. Shiffrin indeed explicitly rejects the idea that there should be any 'lexical hierarchy of value' between different forms of communication. ${ }^{30}$ So either her theory does not do a good job in explaining US or English free speech doctrine in the context of defamation law, or we must conclude that the courts (and the UK Parliament in the recent Defamation Act) have misapplied free speech principles in this area.

There are, it seems to me, other problems with the application of a thinker-based approach to freedom of speech as it is actually exercised in a modern society. Shiffrin's approach proceeds, as we have seen, from the vital role that free and open expression plays in the development of each person as a thinker. The opportunity to exchange ideas and information is essential for all of us to discharge our duties to one another to support such personal development. ${ }^{31}$ How does this argument apply to what has been termed 'mass speech'? ${ }^{32}$ Even in the age of the Internet, free speech rights are now

\footnotetext{
${ }^{28}$ NYT v Sullivan 376 US 254 (1964).

29 Defamation Act 2013, s 4, replacing the common law qualified privilege defence formulated by the House of Lords in Reynolds $v$ Times Newspapers Ltd [2001] 2 AC 127.

${ }^{30}$ Shiffrin, 94.

31 Ibid., 80.

32 The term is used by Lucas Powe in the title of his article 'Mass Speech and the Newer First Amendment' [1982] Supreme Court Review 243.
} 
most often claimed by media organizations, commercial corporations, professional bodies and political parties, rather than by discrete individuals. The communications of these groups do not necessarily reveal the thoughts of any particular person, but are the result of a production team, to which admittedly a number of individuals contribute.

I am also unsure whether and how Shiffrin would apply her theory to the mass mailings of political parties, pressure groups, and charities, which are clearly covered by free speech law, but which are difficult to explain in terms of the moral and intellectual development of individual thinkers. Like other types of mass speech, these communications rarely emanate directly from the thought processes of particular individuals, but are the product of team work. As mentioned earlier, she would exclude commercial advertising and corporate speech from her theory, as does Ed Baker from his liberty model of freedom of speech, but apparently not the speech of media corporations. ${ }^{33}$ Is media speech to be protected because of the press freedom limb of the First Amendment, or because protection is warranted on the thinker-based approach? Of course, the interests of readers, listeners, and viewers - in the acquisition of information and ideas - explain the protection of media speech, just as they also to some extent may warrant the protection of commercial speech and advertising under a free speech clause. ${ }^{34}$ But to admit that point seems to me to weaken the force of Shiffrin's approach which in her view underlies free speech arguments based on the particular interests of either listener or speaker; a reader in my view has an interest in knowing what a newspaper or advertiser wants to tell her, irrespective of whether that advances her moral agency or intellectual development, or whether the communication promotes her relationship with its producer.

I also agree with James Weinstein's criticism that Shiffrin's reluctance to distinguish between different categories of speech might have the unfortunate consequence that political speech, in

\footnotetext{
${ }^{33}$ Shiffrin, 98 writes: ' ...nonpress, business corporate, and commercial speech may differ from individual speech...'.

${ }^{34}$ Shiffrin's approach to commercial speech is criticised on this ground by E Volokh, 'Speech Restrictions That Don't Much Affect the Autonomy of Speakers' (2011) 27 Constitutional Commentary 347.
} 
particular radical dissent, will lose its privileged position. ${ }^{35}$ The same government arguments - safeguarding national security, ensuring public safety and order - which can be used to justify banning the dissemination of dangerous scientific information (for example, how to produce a virulent biotoxin or nuclear weapon ${ }^{36}$ ) could also be employed to defend suppressing the circulation of radical political speech; for on Shiffrin's theory no form of speech is entitled to more protection than the others, so political speech must be treated in the same way as scientific literature. Weinstein also points out that sexually-harassing speech targeted at an individual might enjoy free speech protection on Shiffrin's theory, for it discloses to the victim how the harasser is thinking. ${ }^{37}$ That sort of speech would not enjoy any protection under the public discourse theory, for it is not intended to, and does not, make any contribution to the discussion of a matter on which society has to make up its mind. Shiffrin surely does not contemplate the possibility of protection for the communications of, for example, terrorists and paedophiles, because they reveal how they are thinking. But that is a possibility if we are unwilling to draw distinctions between categories of speech.

Any attempt to draw distinctions between different categories of speech admittedly carries dangers, in particular the risk that government can proscribe some types of discussion - say on sexual matters - while allowing others. As Schauer has argued, ${ }^{38}$ the categories must be consistent with the overall purpose of the constitutional provision guaranteeing freedom of speech, and they must not be so vague that they create a chilling effect on the dissemination of valuable speech and allow the courts too wide a discretion when to uphold speech regulation. Courts in all jurisdictions do draw distinctions between different categories of speech, though they may do this by recourse to different techniques. In the USA, some types of speech, for example, hard-core and child pornography fall outside the scope of the First Amendment altogether, while under the European

\footnotetext{
${ }^{35} \mathrm{~J}$ Weinstein, 'Seana Shiffrin's Thinker-Based Theory of Free Speech: Elegant and Insightful, but Will It Work in Practice?' (2011) 27 Constitutional Commentary 385, 39-92.

${ }^{36}$ In US v Progressive, Inc 467 F Supp 990 (1979) a federal District court even granted a temporary injunction to stop the circulation of information which might enable readers to manufacture a nuclear bomb.

${ }^{37}$ Weinstein (n 35) 392-93.

${ }^{38}$ F Schauer, 'Categories and the First Amendment; a Play in Three Acts' (1981) 34 Vanderbilt Law Rev 265, 282-96.
} 
Human Rights Convention courts are more willing to uphold national restrictions on sexually explicit or commercial speech than they are on political speech as proportionate limitations on freedom of expression. The refusal of the thinker-based approach to countenance any distinction between different categories of speech is surely a weakness in the theory.

However, Shiffrin's approach does explain why private communications among friends and between members of a family, and for that matter between individuals generally, should enjoy full free speech protection. Consequently, she finds disconcerting Robert Post's scepticism whether family discussions, even on presidential politics, are covered by the First Amendment as they do not form part of public discourse. ${ }^{39}$ Perhaps paradoxically, her theory best explains why free speech protection is justified in circumstances where there has been least need of it: for personal conversations and for the revelation of private thoughts in letters and diaries. For as with freedom of thought, governments, except in Orwell's nightmare dystopia, rarely attempt to interfere with purely private communications. ${ }^{40}$ The advent of email, Internet discussion groups, and now of the social media does give Shiffrin's theory much more practical mileage than it would have enjoyed twenty years ago. But I am doubtful whether this point compensates for the weaknesses discussed in the previous paragraphs.

\section{POLITICAL PHILOSOPHY AND CONSTITUTIONAL LAW}

Chapter 3 of Speech Matters implicitly raises questions about the relationship of abstract political and moral philosophy to constitutional legal reasoning. How much account must a free speech theory take of the free speech jurisprudence of constitutional and other courts or is it reasonable to formulate such a theory without regard to how free speech has been understood by the courts? Should it attempt to explain and justify that jurisprudence so far as it can or, if it cannot do this, dismiss the court rulings as simply wrong? Of course, courts, particularly constitutional courts called on to interpret and apply freedom of speech provisions such as the First Amendment or Article 5 of the German Basic Law, must themselves

\footnotetext{
39 See Shiffrin, 84, n 6, commenting on Post (n 25).

${ }^{40}$ Schauer in Free Speech (n 16) 93 says the principle of freedom of thought has limited utility.
} 
consider which, if any, free speech theory underlies the constitutional text. There are then questions how seriously we should take the arguments of the courts and of great judges such as Justice Holmes or Justice Brandeis in leading cases, when we consider whether a particular free speech theory stands up or is found wanting. But the approach of courts and constitutional commentators to the construction of a free speech theory may be quite different from that adopted by philosophers, for courts and commentators are concerned with the principles underlying a text in a particular constitution. ${ }^{41}$ And they do that for a particular purpose, for example, to decide how far the free speech provision covers the dissemination of hard-core pornography or the extent to which 'speech' includes conduct - the burning of a draft card - which can be understood to communicate a message.

Some approaches to freedom of speech surely belong to the realm of ideal political theory rather than to that of constitutional interpretation. Mill's argument from truth is one good example of the former approach. Although the opening paragraph of 'Of the Liberty of Thought and Discussion' refers to English press law, Mill was more anxious about the dangers to freedom of speech from social pressures on the individual than he was about its legal suppression and regulation. ${ }^{42}$ When he wrote the essay, English law lacked any statutory provision protecting free speech, let alone a constitutional clause like the First Amendment, so he could not have been concerned with its meaning. So it makes little sense to ask whether Mill would have extended a free speech guarantee to protect individuals against private as well as government censorship - though for what it is worth I do think his argument should lead us to question some types of non-state action limiting freedom of expression. Further, his preoccupation with the social intolerance of dissenting opinion may explain his lack of apparent concern with libel and contempt of court laws, which were vigorously enforced in the nineteenth century.

Seana Shiffrin's theory equally seems to belong to the realm of abstract or ideal philosophy. It would then be wrong to expect it to have taken much account of First Amendment doctrine and case

\footnotetext{
${ }^{41}$ See the distinction drawn by Fred Schauer between the approach of an 'ideal political theory' and that concerned with the theory underlying a particular constitutional clause in 'Must Speech Be Special?' (n 16) 1305-1306.

${ }^{42}$ On Liberty (n 6) 20-21, 37.
} 
law, though that 'omission' might reduce its significance for First Amendment commentators. ${ }^{43}$ Some passages in chapter 3 of Speech Matters suggest that the thinker-based approach is intended to shed light on free speech jurisprudence, which I take to be broadly the same as explaining and justifying it. ${ }^{44}$ Others suggest a more modest ambition: her theory should be 'compatible with the institutional forms and limits we think sensible. ${ }^{45}$ It need not provide a full account of the scope of institutional free speech protection and the limits imposed on its exercise.

At this point, Shiffrin has to resort to other arguments to explain the relevance of her theory for US constitutional jurisprudence, for example, the limited ability of courts to enforce the positive rights to education which would in principle be warranted by moral requirements to promote the intellectual development of individual thinkers. She also considers that there may be sound reasons to regard state or government interference as a greater threat to free speech than that emanating from private sources - say, media corporations - or resulting from the enormous disparities in personal wealth which distort political debate. Admitting the relevance of these arguments does go some way to 'reconciling' the thinker-based approach with principles of US constitutional law - for example, the 'state action' doctrine under which constitutional rights are guaranteed only against infringement by government. But arguably their admission compromises the attractiveness of the thinker-based approach as a moral argument for freedom of speech - an argument which certainly outlaws private as well as state censorship, ${ }^{46}$ and which might in some circumstances even impose moral duties on both institutions and individuals to communicate openly with others in order to promote their intellectual development.

There is, then, in my view a tension between the integrity of Shiffrin's thinker-based approach and her need to employ it for illuminating (United States) free speech jurisprudence. This tension, it seems to me, is inevitable with any argument for an abstract free speech principle which is formulated apart from the untidiness of particular constitutional arrangements and case law. It is much less

\footnotetext{
${ }^{43}$ This is James Weinstein's view: see (n 35) 388-89.

${ }^{44}$ Shiffrin, 82, 106.

${ }^{45}$ Ibid., 107.

${ }^{46}$ Shiffrin, 108.
} 
felt with the argument for free speech from democracy, particularly with the more sophisticated 'public discourse' version advocated by Post and Weinstein. These theories are more clearly rooted in particular constitutional texts and take account of the jurisprudence of the Supreme (or other constitutional) Court. That is the reason why they are probably more attractive to constitutional lawyers and commentators. But other moral arguments for the value of freedom of speech and communication may philosophically be as, or even more, persuasive just because they are formulated without reliance on any text or set of democratic political institutions. This is true of Shiffrin's fertile thinker-based approach.

\section{OPEN ACCESS}

This article is distributed under the terms of the Creative Commons Attribution 4.0 International License (http: / / creativecommons.org/licenses/by/4.0/), which permits unrestricted use, distribution, and reproduction in any medium, provided you give appropriate credit to the original author(s) and the source, provide a link to the Creative Commons license, and indicate if changes were made.

Publisher's Note Springer Nature remains neutral with regard to jurisdictional claims in published maps and institutional affiliations. 